\title{
Analysis and Determinants of Profit Efficiency of Cassava Farmers in Cross River State, Nigeria
}

\author{
Ettah O. I. ${ }^{* 1}$, Kuye O.O. ${ }^{2}$ \\ *1,2 Department of Agricultural Economics and Extension, Cross River State University of Science and Technology, Obubra \\ Campus, Calabar, Nigeria.
}

\begin{abstract}
A study on the analysis and determinants of profit efficiency of cassava farmers in Cross River State, Nigeria was carried out using the stochastic frontier profit function of Cobb-Douglas functional form. Data for the study were collected from primary sources with the aid of a set of structured and pre-tested questionnaires. For the determinants of profit efficiency, the minimum and maximum profit efficiency was 0.14 and 0.91 respectively with mean profit efficiency of 0.65 . The mean profit efficiency implies that farmers were able to obtain $65 \%$ of their potential profit from a unit mix of inputs. In other words, about $35 \%$ of the profit is lost to inefficiency of management. Thus in the short run, there is a scope for increasing profit from cassava production by 35\%. Age (0.37), education (0.67) and household size (0.58) had positive impact on profit inefficiency. The analysis of profit inefficiency effect showed a significant gamma $(\gamma=$ 0.86). This implies that $86 \%$ deviation from maximum profit obtainable was as a result of inefficiency of the farmers rather than random error or variability. The signs and significance of the estimated coefficients in the inefficiency model have important implication on profit efficiency of the farmers. It is recommended that farmers should be encouraged to invest in cassava production for its profitability and economic value, inputs should be made available and at affordable prices especially improved varieties of cassava cuttings and cassava farmers should be encouraged to receive training on proper agronomic practices and usage of inputs to enhance profit efficiency of input use.
\end{abstract}

Keywords-Cassava, profit efficiency, profit function, farmers and determinants.

\section{INTRODUCTION}

Profit is the excess of revenue over costs. There are basically two concepts of profits. These are the accounting and economic profits. In arriving at the accounting profit, only explicit costs are considered while the economic profit concept accounts for both implicit and explicit costs (Kolawole, 2006). Thus economic profit concept records higher amount of total cost and lower total profit relative to accounting profit. Arene (2000) noted that no alternative hypothesis explains and predicts the behaviour of firms better than the profit maximizing assumption. Olayide and Heady (1982) had earlier affirmed that all other objectives are secondary to profit maximization in the multi-dimensional and/or multivariate motives of enterprise objective. One of the methods of calculating profit is the Gross Margin Analysis.

Efficiency means the production situation where there is no waste. Thus, production efficiency occurs at the point where there is minimum cost of production Olayide and Heady (1982) and Ettah and Nweze (2016) noted that profit efficiency is a concept used in assessing whether an input is expending an optimally balanced level of rent for the use of such a capital. It is an economic performance measure of farms (Adesina \& Djato, 1997). Output that provide insufficient returns to the input used are said to be profit inefficient and such inputs should be moved to alternative investments where the perceived returns is higher. Profit efficient farmers are those paying the minimum profit to owners of inputs (Ettah and Nweze, 2016)

Cassava (Manihot esculenta) is a perennial woody shrub of the euphorbiaceae family. It is grown principally for it tuberous root but it leaves are also eaten in some parts of Africa and used as animal feeds as well. In terms of it nutritional value, cassava roots contains about 60 percent of water and are rich in carbohydrates (Yakassai, 2010). The roots are low in protein and lipids but reasonably rich in calcium and vitamin. Products from cassava when consumed with energy dense protein and nutrient rich supplementary foods such as beans and oil seeds, fishes and pulses provides energy in adequate diet (FAO, 2009). In Nigeria, cassava production is well developed as an organized agricultural crop. It has a well- established multiplication and processing technique for food products and livestock feeds. Though the crop is produced in 24 of the 36 states in the country, cassava production dominates the southern parts of the country, both in terms of area covered and number of farmers growing the crop. The 
major states of Nigeria which produce cassava are Benue, Cross River, Anambra, Delta, Edo, Imo, Oyo and Rivers States and to lesser extent Kwara and Ondo States.

Cassava displays an exceptional ability to adapt to climate changes. It is tolerant to low soil fertility, resistant to drought conditions, pests and disease and suitability to store it root for long periods underground even after maturity, this could be the reason why the crop is the most favourite among the farmers in the area. Hence it is grown throughout the year making it preferable to the seasonal crops of yam, beans, pea, etc. Use of fertilizer is limited and it is also grown in fallow lands. The land holding for farming in Nigeria is between $0.5-2.5$ hectares $(1.2-6.2$ acres $)$, with about 92 percent of producers being small scale farmers, as in many other crops (Yakassai, 2010). In Cross River State, Nigeria, cassava is widely cultivated in the state and grows in all the 18 local government areas. The study therefore seeks to achieve the following objectives: assess profit efficiency of cassava farmers; examine the determinants of profit efficiency; and make policy recommendations.

\section{MATERIALS AND METHODS}

\subsection{The study}

The study area is Cross River State, Nigeria chosen purposively for this study because of the peculiarity of this research problem in the area and the familiarity of the researcher to the area, factors that facilitated data generation. The state lies between latitude $4^{\circ} 15^{1}$ North and $7^{\circ} 00^{1}$ North and longitude $7^{\circ} 15^{1}$ East and $9^{\circ} 30^{1}$ East. (Cross River Ministry of Lands and Survey Bulletin, 2010). The land area of Cross River State is about 7,782 square miles or 20,156 square kilometres (Federal Office of Statistics (FOS), 2007) and the population estimated at 2,888,966 persons (NPC, 2006). Cross River State, Nigeria has a climate made up of two distinct seasons-the dry and wet seasons. The dry season spans from November to late March, while rainy season spans from April to October with a short break in August called "August break". The mean annual rainfall is between $1,300 \mathrm{~mm}$ to $3,000 \mathrm{~mm}$, which varies from place to place across the state (Cross River State Tourism Guide, 2010). According to the tourism guide, highest temperature is recorded between February and March and does not exceed $37^{\circ} \mathrm{C}$ and the lowest between May and October and does not go below $15^{\circ} \mathrm{C}$ and also varies from place to place. The vegetation of the state includes the following: Mangrove Swamp (wetland), rainforest, derived savannah and parkland (Cross River Tourism Bulletin, 2010). Deep laterite fertile and dark clayey basalt soil is found in the area.

\subsection{Sampling Procedure}

Cassava farmers from Cross River State, Nigeria formed the population for this study. A three stage random sampling technique was used to select respondents for the study. The three agricultural zones (Calabar, Ikom and Ogoja) of the state where covered. Three local government areas each were selected randomly from each of the three agricultural zones in the first stage. This gave a total number of nine local government areas in the sample.The second stage involved the random selection of three cassava farming communities from each of the nine local government areas previously selected making a total of twenty seven cassava farming communities. The third stage involved a random selection of four cassava farmers from each of the twenty seven cassava farming communities making a total of 108 respondents for the study.

\subsection{Data Collection and Analysis}

Data required for this study was generated from primary sources. The primary data was collected using a set of pre-tested structured questionnaires. The questionnaire captured information on the socio-economic characteristics of respondents. The questionnaires were administered by well-trained enumerators, who were conversant with the selected locality. Primary data were also obtained through personal contact, oral interviews, etc. The stochastic frontier profit function using CobbDouglas functional form was used for the analysis.

\subsection{Validation and Reliability of Questionnaire.}

The instrument for data collection in this study was validated by passing them through erudite scholars to ensure that it possessed both face and content validity. In other to check the consistency of the measuring instrument over time, reliability test was conducted using the test-retest method. A coefficient of 0.79 was obtained using the Cronbach Alpha Technique indicating the suitability of the instrument for use. A pilot study was then conducted where enumerators were used for pretesting of the questionnaire. This was to avoid inconsistency and incomplete response and also ensure clear understanding of the instrument.

\subsection{Model Specification}

The stochastic frontier profit function using CobbDouglas functional form used for the analysis is specified below as:

$l_{\mathrm{n}} \mathrm{C}=\beta_{\mathrm{o}} \mathrm{Y}^{*}+\beta_{1} l_{\mathrm{n}} \mathrm{X}_{1}+\beta_{2} \ln _{\mathrm{n}} \mathrm{x}_{2}+\mathrm{l}_{3} \mathrm{~L}_{\mathrm{n}} \mathrm{X}_{3}+\beta_{4} \mathrm{l}_{\mathrm{n}} \mathrm{X}_{4}+\beta_{5} \mathrm{l}_{\mathrm{n}} \mathrm{X}_{5}$ $+\beta_{6} l_{n} X_{6}$

$\ln =$ Logarithm to base

$\mathrm{C}=$ Gross margin $(\#)$

$\mathrm{Y}^{*}=$ Cassava output $(\mathrm{Kg})$

$\mathrm{X}_{1}=$ Land rent per ha

$\mathrm{X}_{2}=$ Cost of hired labour used in Cassava production per ha

$\mathrm{X}_{3}=$ Price of cassava cuttings 
$\mathrm{X}_{4}=$ Price of Agrochemical per litre

$\mathrm{X}_{5}=$ Price of fertilizer per $\mathrm{kg}$

$\mathrm{X}_{6}=$ Price of capital inputs ( $)$

$\mathrm{U}_{1}=$ error term

$\beta_{\mathrm{o}}=$ Constant term

$\beta_{1}-\beta_{2}$ $\beta_{6}=$ Regression coefficients

$\mathrm{U}_{\mathrm{i}}=$ are random variables which are assumed to be independent and normally distributed with zero mean and constant variance $\mathrm{Vi}-\mathrm{N}\left(0, \delta^{2}\right)$, which are non -negative random variables and are assumed to account for technical inefficiency in production (Aigner, Lovell \& Schmidt, 1977).

The determinant of profit inefficiency is defined by:

$\mathrm{Ui}=\delta_{0}+\delta, \mathrm{z}_{1}+\delta_{2} \mathrm{z}_{2 \mathrm{i}}+\delta_{3 i} z_{3 i}+\delta_{4} 2_{4 i}+\delta_{5} z_{5 i}+$

$\delta_{6} z_{6 i}+\delta_{7} z_{7 i}+$

Where:

$\mathrm{Ui}=$ profit inefficiency

$\mathrm{Z}_{1}=$ Farmers' age (years)

$\mathrm{Z}_{2}=$ Farming experience (years)

$\mathrm{Z}_{3}=$ Education (years)

$\mathrm{Z}_{4}=$ Training ( 1 if received training, 0 otherwise)

$\mathrm{Z}_{5}=$ Membership of farmers' association (1, yes, 0 , no)

$\mathrm{Z}_{6}=$ Household size

$\mathrm{Z}_{7}=\operatorname{Sex}(1$, Male, 0 , Female) $\delta_{0}-\delta_{7}=$ parameters 1977).

(Aigner, Lovell \& Schmidt,

\section{RESULTS AND DISCUSSIONS 3.1 Determinants of Profit Efficiency of Cassava Farmers}

The profit efficiency of the respondents is shown in table 1. $7.4 \%$ of the respondents had a profit efficiency of less than or equal to $0.2,27.7 \%$ had $0.21-0.40,41.6 \%$ had $0.41-0.60,13.8 \%$ had $0.61-0.80$ and $9.3 \%$ had $0.81-1.0$. The minimum and maximum profit efficiency was 0.14 and 0.91 respectively with mean profit efficiency of 0.65 . The mean profit efficiency implies that farmers were able to obtain $65 \%$ of their potential profit from a unit mix of inputs. In other words, about $35 \%$ of the profit is lost to inefficiency of management. Thus in a short run, there is a scope for increasing profit from cassava production by $35 \%$. This result is in consonance with the findings of Otitoju (2011) who reported a mean profit efficiency of 0.67 for crop farmers in southwestern Nigeria. The result is lower than the result of Iorlamen (2015) who reported a mean profit efficiency of 0.59 for sesame farmers in Benue State, Nigeria.

Table.1: Profit Efficiency

\begin{tabular}{lcl}
\hline Profit efficiency range & frequency & percentage \\
\hline$<0.2$ & 8 & 7.4 \\
$0.21-0.40$ & 30 & 27.7 \\
$0.41-0.60$ & 45 & 41.6 \\
$0.61-0.80$ & 15 & 13.8 \\
$0.81-1.00$ & 10 & 9.3 \\
Total & $\mathbf{1 0 8}$ & $\mathbf{1 0 0}$ \\
Minimum & 0.14 & \\
Maximum & 0.91 & \\
Mean & 0.65 & \\
Mean of best ten & 0.81 & \\
Mean of worst ten & 0.16 & \\
\hline
\end{tabular}

Source: field Survey, 2016.

\subsection{Factors Influencing Profit Efficiency of Cassava farmers}

The parameter estimates of the influence of socioeconomic factors on profit inefficiency of cassava farmers are presented in the lower section of Table 2. The analysis of profit inefficiency effect showed a significant gamma $(\gamma=0.86)$. This implies that $86 \%$ deviation from maximum profit obtainable was as a result of inefficiency of the farmers rather than random error or variability. The signs and significance of the estimated coefficients in the inefficiency model have important implication on profit efficiency of the farmers. The estimated coefficient for age (0.37) was positive and significant at $1 \%$ level. The positive relationship implies that as age of farmers increases, the level of profit inefficiency tends to increase thereby decreasing profit efficiency.This could be that as the farmers get older, the less efficient his supervision. This finding is in line with the work of Abu et al., (2012) and Arene, (2000) where age positively contributed to profit inefficiency among sesame farmers in Nassarawa and Benue States of Nigeria respectively.

A direct and significant relationship was found between education (0.67) at $1 \%$ probability level and profit inefficiency. This implies that an increase in the level of 
education increases the level of profit inefficiency (i.e. decrease profit efficiency). The positive value obtained is unexpected as farmers may go in search of white collar jobs thereby neglecting the farming sector or paying little or no attention to it. This findings disagrees with the work of Tanko, Ajani \&Adeniyi (2012) that education decreases profit inefficiency in rice farming. The finding agrees with that of Iorlamen (2015) that education increases profit inefficiency in rice farming. The estimated coefficient for farming experience $(-0.21)$ significant at $5 \%$ level of probability was negative and significant implying that, increase in farming experience tends to decrease the level of profit inefficiency (i.e. increase profit efficiency). This findings is in consonance with the findings of Kolawole (2006) and Abu and Abah (2012) who found that increase in farming experience decrease profit inefficiency of small rice farmers in Nigeria and female small holder farmers in Atiba local government area of Oyo State, Nigeria respectively.

Household size (0.8) had positive and significant relationship on profit inefficiency at $5 \%$ probability level. This implies that, increase in household size increases profit inefficiency (i.e. decrease profit efficiency). This result is in congruence with findings of Arene (2000) who observed a positive relationship between household size and profit efficiency in sesame production in Benue State. This is contrary to the findings of Nwaru \& Iheke (2012) who found household size to increase profit efficiency among catfish farmers that used kitchen/animal waste. Number of training (5.61) was positively related to profit efficiency at $1 \%$ probability level; this is because training enhances farmers' knowledge about innovations in agricultural production and ease of access to agricultural aids (Adeniji et al., 2005).

The result also showed a negative and significant relationship (-8.06) between membership of association and profit inefficiency at $1 \%$ significance level. Membership of association decreases profit inefficiency and increases profit efficiency. This is expected as farmers membership of association could afford them the opportunity of interacting with other farmers thereby exchanging information on improved technology in farming. Although the result disagrees with the finding of Nweze \& Pamwal (2006). In conclusion, age, education and household size had positive impact on profit inefficiency and this is contrary to apriori expectation regarding the roles of these factors.

Table.2: Factors affecting profit Efficiency of Cassava farmers

\begin{tabular}{llll}
\hline Variable & Coefficient & Standard error & t- ratio \\
\hline Constant & 9.22 & 1.29 & $7.13^{*}$ \\
Output & 0.57 & 0.07 & $8.34^{*}$ \\
Land rent per ha & $-0.94 \times 10^{-2}$ & 0.072 & $-0.13^{* *}$ \\
Hired labour per ha & $-0.72 \times 10^{-2}$ & 0.001 & $-0.69^{*}$ \\
Cuttings per Kg & $0.68 \times 10-2$ & 0.035 & $0.19^{* *}$ \\
Agrochemical price per ha -0.07 & 3.5 & $-0.02^{*}$ \\
& & & \\
Inefficiency Model & & & $-6.13^{*}$ \\
Constant & -38.40 & 6.26 & $4.03^{*}$ \\
Age & 0.37 & 0.092 & $2.08^{* *}$ \\
Farming Experience & -0.21 & 0.047 & $12.54^{*}$ \\
Education & 0.67 & 0.058 & $5.73^{*}$ \\
Number of training & 5.61 & 1.021 & $3.33^{*}$ \\
Member of Association & -8.06 & 2.420 & $1.81^{* *}$ \\
Household size & 0.58 & 0.243 & 0.81 \\
Sex & 0.16 & 0.197 & 10.13 \\
Sigma Squared & 18.66 & 1.842 & 163.19 \\
Gamma & 0.86 & $0.52 \times 10-2$ & \\
Likelihood function & -188.34 & & \\
\hline Source: field survey, 2016 & & & \\
\hline
\end{tabular}

Source: field survey, 2016

$*, * *=\mathrm{t}$ ratio significant at $1 \%$ and $5 \%$ level respectively.

\section{CONCLUSION AND RECOMMENDATIONS}

The study analysed the determinants of profit efficiency of cassava farmers in Cross River State, Nigeria. The specific objectives were to: assess their profit efficiency and examine the determinants of profit efficiency. A three -stage (multistage) random sampling technique was adopted in the selection of 108. Inferential statistical tool used was the stochastic frontier profit model. Analysis 
shows that the mean profit efficiency of cassava farmers was 0.65 with minimum and maximum of 0.14 and 0.91 respectively. This implies that the farmers are not fully profit efficient. Cassava production in the study area is undergoing an increasing return to scale and by this a profitable venture. Factors affecting profit efficiency were age of farmers and education which were positive and significant at $1 \%$. Farming experience and membership of association were negative and significant at $5 \%$ and $1 \%$ respectively. Household size was positive and significant at $5 \%$.

Based on the findings of this study, the following recommendations were made: farmers should be encouraged to invest on cassava production for its profitability and economic value, inputs should be made available and at affordable prices especially improved varieties of cassava cuttings and cassava farmers should be encouraged to receive training on proper agronomic practices and usage of inputs to enhance profit efficiency of input use.

\section{REFERENCES}

[1] Abu, G.A., Ater, P.I \& Abah, D. (2012). Profit efficiency among sesame farmers in Nassarawa State, Nigeria. Journal of Social Sciences, 4(4), 261268.

[2] Adeniji, A. A., Ega, L.A., Akoroda, M.O., Adeniji, B.O., Ugwu, A. \& Balogun, D.A. (2005). Cassava Development in Nigeria. Department of Agriculture, Federal Ministry of Agriculture and Natural Resources, Nigeria. F.A.O. Retrieved 22 September, 2013

[3] Adesina, A. A. \& Djato, K.K. (1997). Relative efficiency of women as farm managers; profit Functional approach in Cote d'voire. Journal of Agricultural Economics 4(12) Pp. 23-30

[4] Aigner, D. K., Lovell, A. K. \& Schmidt, P. (1977). Formulation and estimation of stochastic frontier production function models. Journal of Econometrics, 6(9), 21-37.

[5] Arene, C. J. (2000). Profit function analysis of small ruminants' enterprises in Nsukka L.G.A. of Enugu State; Nigeria. Economic Affairs, 47(4), 209-214.

[6] Cross River State Ministry of Lands and Survey Yearly Bulletin (2010). Handbook for visitors to Cross River State, Calabar, Nigeria.Pp 2-4 Retrieved from www.crs govt.org.ng

[7] Cross River State Tourism Bulletin (2010). Annual publication of tourism potentials of Cross River State, Calabar, Nigeria Pp 3-9.

[8] Ekubika, E. (2010). Economic analysis of cassava production farming in Akwa Ibom State, Nigeria. Agriculture. Biology and Animal science. 4(2).
[9] Ettah, O. I. \& Nweze, N. J. (2016). Analysis and determinants of technical efficiency among cassava farmers in Cross River State, Nigeria. International Journal of Innovative Research and Development, 5(10), 109-113

[10]Federal Office of Statistics, (2007). Annual abstract of Nigeria's statistics 2007, Federal Ministry of Finance, Abuja, Nigeria Pp 27-32.

[11]Food and Agricultural Organisation (2009). Statistical data base: F.A.O. Quarterly bulletin of 2009. pp. 42-47.

[12]Iorlamen, T. (2015). Resource use efficiency of Sesame farmers in Benue State, Unpublished Ph.D. thesis submitted to the Department of Agricultural Economics, University of Nigeria, Nsukka.

[13] Kolawole, O. (2006). Determinants of profit efficiency among small scale rice farmers in Nigeria: a profit function approach. Poster paper presented at the International Association of Agricultural Economists Conference, Gold Coast, Australia August 12-18.

[14] National population commission, (2006). Census enumeration survey N. P. C. Abuja, Nigeria. Pp 68. Nigeria.

[15] Nwaru, J. C. \& Iheke, R. O. (2012).Comparative analysis of resource use in rice production systems in Abia State, Nigeria. International Journal of Agriculture, Environment, 2(4), 8-20.

[16] Nweze, N. J. \& Panwal E. F. (2006). Resource- use and productivity among rainfed and irrigated Irish Potato Producers in Plateau State, Nigeria. A paper presented at $20^{\text {th }}$ Annual National Conference of Farm Management Association of Nigeria, held at Forestry Research Institute of Nigeria, Federal College of Forestry, Jos Plateau, $18^{\text {th }}-21^{\text {st }}$ September.

[17] Olayide, S. O. \& Heady, E.O. (1982). Introduction to agricultural production economics. Ibadan University Press, Ibadan, Nigeria.

[18] Otitoju, A. (2011). Influence of climate change adaptation strategies on efficiency in food crop production in Southern Nigeria. An unpublished Ph.D. thesis submitted to the Department of Agricultural Economics, University of Nigeria, Nsukka.

[19] Tanko, L. Ajani, R. \& Adeniyi, (2012).Relative technical efficiency of credit and non-credit users in rice-based enterprises in Lavun LGA of Niger State, Nigeria. International Journal of Agricultural Economics and Rural Development, 5(4) 20-32.

[20] Yakassai, M. T. (2010). Economic contribution of cassava production (a case study of Kuje area council F.C.T. Abuja Nigeria. Bayero Journal of Pure and Applied Sciences, 3(1), 215-219. 